DOI https://doi.org/10.18551/rjoas.2017-09.21

\title{
CAPABILITY ASSESSMENT OF SMALL AND MEDIUM ENTERPRISES IN KALIMANTAN TIMUR
}

\author{
Hadjaat Michael*, Za Saida Zainurossalamia, Wahyuni Sri \\ Faculty of Economy and Business, Mulawarman University, Indonesia \\ *E-mail: saida.zainurossalamia.za@feb.unmul.ac.id
}

\begin{abstract}
Economically, Small and Medium Enterprises (SMEs) have contributed to economic growth, but in a development deal with complex problems. The existence of SMEs in the region is expected to provide a significant positive contribution to mitigation efforts such problems. These problems lead to weak business networks, the limited ability of market penetration and market diversification, economies of scale is too small that it is difficult to reduce the cost, the profit margin is very small, and others, and do not have a competitive advantage. At this time, innovation has not been a major driver of economic growth and technological progress in Indonesia, particularly SMEs. The success of building innovation capacity is determined by an existence of markets served carefully, the ability to collect valuable information and learning market information. Implementation of innovation is a complex process that requires the harmonization of policies and strategies from many sectors. If it is met, innovation will occur on an ongoing basis and contribute significantly to economic growth.
\end{abstract}

\section{KEY WORDS}

Innovation, capabilities, cluster, SMEs.

Development of Small and Medium Enterprises (SMEs) became a crucial since SMEs have such an important role for the economic growth of a country, including in the country of Indonesia. In Indonesia, SMEs contribute to the employment of $\pm 99 \%$ and contributed to GDP amounted to $\pm 57 \%$. It shows that SMEs have the ability to strengthen the structure of the national economy. Although economically SMEs have a significant contribution to economic growth, but in a development deal with complex problems are: lack of capital, difficulties in marketing, simple organizational structure with a division of labor that is nonstandard, low- quality management, poor quality and limited human resources, most do not have the financial statements, the legality weak, and poor quality of products and technology.

During these SMEs in the region are often associated with economic and social problems in the region itself, such as high levels of poverty; number huge unemployment, especially for the less educated segments of society; unequal distribution of income; process of uneven development between urban and rural as well as urban problem with all its negative aspects. This means that the presence of SMEs in the region is expected to provide a significant positive contribution to mitigation efforts such problems. These problems lead to weak business networks, the limited ability of market penetration and market diversification, economies of scale is too small that it is difficult to reduce the cost, the profit margin is very small, and others, and do not have a competitive advantage. SMEs have competitive advantages, which are: having a good quality of human resources, optimal use of technology, is able to perform efficiency and increase productivity, improve the quality of products, have access to extensive promotion, have a structured quality management system, resource adequate capital, has extensive business network, and have an entrepreneurial spirit and have the ability to be able to innovate.

Innovation is a process with varying levels of difficulty from simple to complex; and that is certainly dynamic (potentially snow-balling effects). As a process in which there are elements of inter-related driving, where there is an interactive learning so successful innovation in the market. Owner ideas or creations certainly cannot act alone, and in turn interact with the market. Progress of science and technology can now be used in the process to become a product idea, do not always have to be intensive in research and development, 
but rather intensive in to the "science and technology" so readily accepted in the market. Not all owners of ideas have the capacity (including mastery of science and technology) are qualified in the success of innovation, in which case it will be necessary support of "ABG" (Academics, Business, and Government) in synergy. Limitation of innovation system as formulated states that there are vertical and horizontal relationships that form a network to a productive process of learning and diffusion results in best practice. Vertical relationship is reflected in the value chain enterprises (cluster) that may result from innovation, while the more horizontal relationship is a relationship between individuals and between institutions that can succeed innovation. The system itself can be interpreted simply as a bond of some of the elements that have a dependency to one another and interact on a regular basis (regular) in performing a task.

Innovation has not been a major driver of economic growth and technological progress in Indonesia. First, the value of innovation Indonesia only factor of 3.6 in 2012. Second, Indonesia is ranked 108 in the world ranking index of the knowledge -based economy. Third, innovation has not been a major part of economic growth is still dependent on the consumption of around $63 \%$ consists of exports and investment demand. Factors contributing consumption dominant cause of economic growth only reached $6.5 \%$ in 2011 that should be higher if supported also by the lack of innovation. Fourth, innovation does not become the focus of a growing industry in Indonesia, especially in the regions, but more as a secondary raw material or component or assembly plants. The importance of innovation capability as an economic force that drives change in the values of economic offer something new in the markets served. The success of building innovation capacity is determined by the existence of markets served carefully, the ability to collect valuable information and learning market information.

Thus there are two things that are important to be able to build innovation capabilities. First; aspects of learning, where the observed and studied market information into knowledge that has important value in order to build competitiveness. Second; related to the ability to be able to attach the market and stakeholder preferences companies that have relevance values are particularly important to catch the signal - a signal of quality products at competitive standardization. It appears that the implementation of the innovation is a complex process that requires the harmonization of policies and strategies from many sectors. If it is met, innovation will occur on an ongoing basis and contribute significantly to economic growth. According to Pavit (2005) the company must be aware that the success of the companies affected by innovations. Innovation is needed because the environment is always changing. When competitors introduce new products to meet the market demand is there, and then the company must respond to the situation. One way to make innovations in order not to be left by customers.

Potential industry owned by SMEs, some of which became the mainstay commodities. The development of the craft, the recently characterized the emergence of a variety of types and appearances with new designs. That is one of the allure for domestic and foreign consumers. Another problem is also felt in terms of technology introduction and application of various technologies can improve the various weaknesses of small entrepreneurs.

With technology, small businesses can produce precise, accurate, and in a short time in accordance with the order. The development of technology is one of the major forces that control industrial growth. The use and management of new technologies is important for small businesses to improve competition and increase both national and international competition. Many authors state that small businesses are far behind compared to large enterprises in the use of new technologies. Some of the reasons for this are the limited resources of small companies. In addition, a national structure for the production and transfer of new information about the technology adopted for business needs a little small. With the help of human technology tend to have a lot of choices in developing areas of interest. In addition, the technology can be used for the welfare of society or improve the quality of life of man.

Many small companies used to buy equipment and fix it by adding functions. Innovation and new technologies require external information in the development of new ideas facility. 
Basically, regional innovation systems may be developed only when there is a strong desire, pioneering and consistency of Regional Head to build competencies and strengthen the synergistic collaboration of various parties in the region's economic development through policies and instruments policy set. In other words, the key to the successful development of regional innovation systems is the presence of a strong will, pioneering and consistency of both the Regional Heads in setting the policy agenda of regional innovation system development, strengthening the framework of regional innovation system elements, as well as in the provision of regional innovation systems development budget is done with; Carrying capacity of the provider; Absorptive capacity of the user; Institutional linkages interface and the parties mutually beneficial; Specialized infrastructure; Funding / financing of innovation and/or funding/financing risk; and policy support.

The objectives of the study are:

- Identify potential SME sector can be the focus of the development of the innovation capability of SMEs;

- Identify stakeholders both in government, academia, private sector, producers, and society;

- Identify the factors of competitive advantage for formulating SME innovation capability of SME development strategy leading sectors.

Expected benefits can be gained from this study include:

- Material inputs to policy makers at the local government in an effort to empower and development of SMEs;

- Efforts to improve the empowerment of government, academics and the business agent for the community is able to drive the innovation potential synergistic owned achieve the development of SMEs in East Kalimantan.

\section{LITERATURE REVIEW}

Innovation as a management process requires systems and culturally appropriate to achieve the effectiveness of the company. Support intangible assets inherent in man as knowledge is indispensable as a source of value for the company. Intellectual assets that the company is highly dependent on intangible characteristics such as: the ability of innovation, the ability to change, the opportunity to market, development and retention of employees, and the relationship with the customer. Two important dimensions necessary to support innovation of the system is that the technology, structure, and processes as well as a good culture include employee commitment, as well as access to talented employees.

Innovation implemented an innovation opportunity search results. Innovation is not just an outcome but it is a process. Formally, according to Law No. 18 In 2002, innovation is research, development, and or engineering that aims to develop practical application value and context to new knowledge or new ways to apply science and technology existing in the product or production process. Innovation can be said is the mobilization of knowledge and technical skills (diffusion of science and technology) as well as experience in creating new processes and outcomes. Innovation is a key driver of long -term success of a company in today's competitive market. This is because companies with the capacity to innovate will be able to respond to environmental challenges faster and better than companies that do not have the capability for it. Therefore, it is not surprising that the effect of innovation on performance has become a classic in the literature of analysis, with a number of empirical studies provide evidence of the positive effects (Jimenez et al., 2008).

Given the importance of innovation in relation to the competitiveness of the company, a number of studies have tried to identify the major determinants of the capacity of companies to innovate (Damanpour, 1991). These factors consist of internal and external factors as antecedents of innovation. Of internal factors studied include strategy, organizational design, leadership or organizational culture (Damanpour, 1991) and, recently, the learning organization and market orientation (Jimenez et al., 2008). Organizational innovation studied from various disciplines, such as management/strategy, entrepreneurship, political science, and marketing. Innovation is a form of learning and something new. 
Innovation is a means through which an organization responds to a variety of environmental changes. Tushman and Nadler (1986) proposed that innovation refers to, product method new ideas, or services that are applied in the organization. Some researchers define innovation as the implementation of new ideas, methods, or services (Subramanian and Nilakanta, 1996), other researchers assume different innovations. For example, Vigoda-Gadot et al. (2005) view innovation as a multi-dimensional nature of the organization. They define innovation as the organization includes five dimensions: creativity, risk taking, openness to change, future orientation, and pro-activeness. Innovation can be distinguished from creativity and consists of four elements, namely, creativity, strategy, application, and profitability (Li-An Ho, 2011). Pavitt (2005) found at the company level, the process of innovation can be divided into three sub-processes include: Cognitive, namely how companies generate and maintain knowledge to perform tasks; Organization, which is how the company operates internally or in collaboration with other companies and organizations, and Economics, which is how the company determines the internal incentives to ensure the rapid innovation and are in the desired direction.

Strategy of Innovation. Innovation has a dual role as a determinant of economic competitiveness and as a means for liberation (liberation) and socio-cultural backwardness, ignorance, and poverty (Bobb, 2005). Success in today's business is determined by innovation. Innovation is defined as a process within the organization to utilize the skills and resources to develop new products or services or to build a new system of production and operations so as to address the needs of customers (Jones, 2004). Technology, business opportunities, capital, entrepreneurship, regulatory and cultural as well as methodologies are variables that affect the practice of innovation in an organization (Abend, 2005). Innovation on the other hand is also a dilemma for management, organizational survival in the long term requires a commitment to always do the transformation through disruptive growth. However, the facts prove only a few companies that can succeed with this strategy. Innovative organization committed to controlling the environment; organizational structure that gives the freedom to be creative; leadership that encourages organizations to innovate, and a management system that serves the mission of the organization. Natural barriers that are often encountered in efforts to innovation, among others; solid organizational structure (dense), resource constraints, the reluctance to delegate authority, and a high level of internal audit. In order to be sustainable innovation and corporate performance required to support innovation strategy (Terziovski and Marianne, 2004), which classifies the innovation strategy into three groups of radical, incremental, and integrated. Radical is a strategy that refers to the activity of innovation that never existed before; drastically change the establishment, products or new processes that differ from the previous. Incremental is gradually developing strategy; repair the product or an existing business processes with innovative measures. Integrated combine radical and incremental addition to finding new things (invention) integrated strategy also encourages innovation by developing of an existing one. In general, innovation has the meaning adopt something new by anyone who adopt it, and as the process of creating new products. Innovation is a multidimensional concept which consists of four dimensions: leadership orientation towards innovation company (Maldique and Patch, 1988), the type of innovation, the source of innovation (Mansfield, 1988) and the required investment in innovation (Thomson and Ewer, 1989).

Here's an explanation of the dimensions of innovation are:

- Leadership orientation; shows the company's position in the market if the company as a fist to the market, the company as the second player second to the market, or a late entrant. The leader is responsible for determining and formulating a strategy in accordance with the company's position in the market.

- Type of innovation; type of innovation represents a combination of manufacturing innovation, which is a process that is carried out and the products produced by the company. Innovation processes emphasis on new methods in the operation by making new technologies or develop existing technologies. While product innovation is the result of the creation and introduction of radical products or modifications of existing products. Technological uncertainty, lack of support from senior managers, 
lack of resources and poor project management will hamper the achievement of product development (Zahra and Das, 1993). The selection of the type of innovation is affected by the company's investment, and will ultimately affect the performance of the company.

- Source of innovation; describes the implementation of innovation activity, whether the idea of innovation comes from internal or external or both. Internal sources of innovation means that the company entrusted to innovate both in the business process or product on research and development section. While external sources of innovation have a sense that the company will perform innovation by way of purchase, the license agreement, the acquisition of another company or partnership (joint venture) with suppliers, customers or other companies.

- The level of investment; the level of investment includes investment in terms of finance, technology and investment in human resources. Financial investment includes expenditures for research and development projects, and the purchase of an innovation in a product that has been developed elsewhere. Technology investment is the expenditure for equipment, infrastructure, human resources. In the face of an increasingly competitive conditions of competition, the business environment is unpredictable and highly competitive consumer demand, sue the company to seek new solutions in formulating corporate strategy in order to maintain the viability and competitiveness of the company. Particularly in terms of product development innovation strategy needs to be developed and continue to do (never ending innovation). Without innovation companies will die otherwise companies that sustainable innovation or continuously will be able to dominate the market, with the creation, capital, new product appearance.

Economic Clustet. Cluster (cluster) is essentially an attempt to classify interconnected core industry, both supporting industries (supporting industries), industry -related (related industries), supporting services, infrastructure, research, training, education, information infrastructure, technology infrastructure, resources natural resources, and institutions institutions. The cluster is also a way to set some economic development activity. Porter (1990) defines Clusters as "Clusters are geographic concentrations of firms, suppliers, related industries, and specialized institutions that occur in a particular field in a nation, state, or city. Another definition of Clusters industry is the geographical concentration of industries that gain performance advantages through co-location. Clusters can also be defined as "the relationship between the company also provides various complementary services, including consultancy services, education and training providers, financial institutions, professional associations and government institutions".

There are at least three forms Cluster frameworks: Diamond models, flexible specialization and collective efficiency. Flexible models and specialization widely adopted by developing countries. Porter diamond models widely applied in developed countries. Model diamond is considered superior to other models in explaining Clusters are dynamic and have a great role in improving productivity through industrialization process. Cluster approach Porter's model is the development of industrial district or industrial areas developed by Alfred Marshall in 1920. In contrast to Marshall who only focuses on peer companies, Cluster Porter's model does not restrict to just one industry, but more broadly.

Diamond Cluster Model, includes related industries, as well as other companies that have relevance in technology, the same input. By working together in a cluster, then the firms or industry - related industries will benefit from synergies and efficiencies are high compared to those working on their own. According to Porter (1990) Clusters can be formed in the city, the region, and even within a country. Cluster (cluster) is essentially an attempt to classify interconnected core industry, both supporting industries (supporting industries), related industries (related industries), supporting services, infrastructure, research, training, education, information infrastructure, technology infrastructure, resources natural resources, and institutions - institutions. The cluster is also a way to set some economic development activity. Among some very fundamental truth in the concept of industrial clusters and distinguish one concept with other concepts are the dimensions value (value chain). With 
consideration of the value chain dimension, in general there are two (2) industry cluster approach in the literature, namely:

- Some of the literature, especially that developed in advance and further highlights aspects of agglomeration, an approach based on (emphasis on) aspects of similarity (similarity) a set of business activity. In this case for example, industrial centers / business, industrial district, and the like that have a " likeness " of business activity is regarded as an industry cluster;

- Some of the growing literature today, including those emphasized by Porter, an approach highlights the " linkage " (interdependency) or a set of business activities of the value chain. In this view, the central industrial / business and / or industrial district is basically an integral part of the fabric of the value chain as an industry cluster. Assessed value chain approach " more appropriate " especially in the context of increasing competitiveness, innovation systems development (national / local), economic development initiatives knowledge / technology or themes like, and not " just" an attempt to obtain " agglomeration economies " as a similar concentration of business activity. In detail, there are several definitions of the cluster. Porter (1990) defines Clusters as "Clusters are geographic concentrations of firms, suppliers, related industries, and specialized institutions that occurs in a particular field in a nation, state, or city". Another definition of Clusters industry is "the geographical concentration of industries that gain performance advantages through co-location". Clusters can also be defined as "the relationship between the company also provides various complementary services, including consultancy services, education and training providers, financial institutions, professional associations and government institutions.

The Benefits of Clusters. Targeting industrial cluster development program with the industry believed Porter will provide great benefits to economic growth.

The benefits of these clusters are as follows (Porter, 1990):

- Cluster is able to strengthen the local economy industry concentration at a particular location may have an impact on cost savings for companies in the Cluster. The cost savings are known as localization economies. The savings can be derived from the increased availability of specialized input suppliers and services; addition of trained and specialized workforce; public infrastructure investments are done for the needs of specific industries; Financial markets are closely associated with the industry; and the increasing trend of information and technology transfer between the companies.

- Cluster is able to facilitate the reorganization industrial transition from the industrial organization of large companies that produce en masse to a small company that focuses on the specialty production has been well documented. Changes in industry structure occur due to increased global competition and the emergence of new production technologies (eg: computerized production). Cluster is an attractive industrial location for a small company specialized in the production and computerized. Product specialization and the adoption of the latest production technology is more prominent and easy to do for the company in the industrial cluster. The closeness between the company specialized in the production of input suppliers and product markets can increasing the flow of goods through the production system. Readiness for access to market products and inputs also allow the company to adapt to the changes that occur in the market. Thus, the spatial concentration of these companies are able to provide a collection of well-trained workforce that is required by a computerized production technologies.

- Cluster improve networking among companies. Networking is a collaboration between the companies to take advantage of cooperation, develop new markets, integrating activity, or gather resources and knowledge. This cooperation will often occur naturally among cluster members. A survey of manufacturing networks shows that companies that have strong networking benefit from collaboration and transfer of information on marketing, new product development, and technology improvement. 
These companies also increased competitiveness and profitability through cooperation and collaboration between the companies.

- Cluster allows a focus on public resources. Targeting industrial development through cluster allows a region to use the resources of economic development privately held more efficiently. First, industrial cluster allows a region to focus on the recruitment system, maintenance and expansion, as well as small business development programs rather than providing assistance programs for a variety of different types of industries. Planned development efforts such as these provide a clearer identification of the needs of specific industries and allow (with specific spending budget) program providing fewer, but more valuable. Second, because the relationship between companies in the Cluster, programs that support specific business will have a multiplier effect (multiplier effect) is relatively greater to the regional economy. Total employment and income of the form (or retain) Cluster members will exceed total employment and income of the companies of the same amount, but not incorporated in the Cluster.

- Clusters increase productivity and efficiency. With the Clusters then the efficiency will be created in economy. The companies will have access to certain inputs, services performed, labor, information, because it is available in the cluster. Likewise, the coordination between companies in Clusters will be established better and easier. Best practices in Clusters will be faster transmitted so that maximum efficiency will be obtained by many companies.

- Clusters encourage and facilitate innovation. The existence of clusters will increase the ability of members of the Cluster to see opportunities to perform a variety of innovations. Ease of doing experiments with the use of existing resources in the cluster are also other benefits of the ClusterCluster model is very effective for the economy because Cluster provides several benefits. First, an integrative approach Cluster will create coherence of the various activities or projects separate activity. Second, a comprehensive cluster approach, collaboration and cooperation will create synergy in the Cluster. Third, the Cluster will encourage innovation, which in turn will increase productivity.

Clusters vs. Industrial Targeting. Porter stated that what is important is not what is produced in a country or region, but rather how the production productive in increasing growth and competitiveness. Theoretically, any region or country can develop a cluster with competitiveness if they focus on improving productivity. Porter added, "All Clusters matter" (all important Clusters), this opinion may be very surprising for policy makers who are just looking for seed industry (pick the winners). Furthermore, Porter also stressed that "there is no low-tech industry; there is only a low-tech company". In other words, we do not have to do industrial targeting.

Differences between economic developments based on traditional industrial clusters policy. The main difference lies in the first line: if the industrial policy of targeting specific sectors of industrial progress and desired, Cluster approach believe that all Cluster contribute to progress together. The problem, policy analysts just want to know which is more important clusters, targeting the high-tech industry, and it was generally believed that what produced an area (and not how) is vital for the development of strategic policy. This leads to "all Clusters matter" looks like is not part of a strategy. Porter actually believe that traded "Clusters (Cluster export oriented or economic activity) is more important than the "nontraded" Clusters.

In this case, Porter Cluster theory is an extension of the regional economic theory that has been adopted by most local authorities, which "traded Clusters" role as a major driver of economic growth and expanded through forward and backward linkages. Cluster identification generally based on input-output analysis, although this approach is more oriented look backward and forward linkages relations in industrial environments. Porter did not like the input-output analysis. He looked at the relationship between the company, not as a backward and forward linkages relationship, but the relationship technology, expertise, information, marketing and consumer desires, where Porter regard it as a main component to 
create competitiveness and innovation. But Porter also know that the sector is "traded", which is a traded commodity sector, has a major role in development.

Critical Success Factors Clusters. There are several factors that determine the success of a cluster. These factors are the presence of venture capital; the availability of technical infrastructure, the presence of higher education and research institutions, entrepreneurs, networking and quality of linkages, social capital and diversity. Various studies on clusters also found that the cluster that has the competitive environment and their rivalry will be more developed than the cluster that are highly dependent on natural resources, weather and geography.

There are important factors that led to Taiwan succeeded in developing Clusters industry since the 1980s. First, the government's role is very important in the early stages of establishment Clusters by encouraging innovation through research institutions like ITRI and the Institute for Information Industry (III). With the innovation, Clusters grow quickly. The government in the early stages also provide fiscal incentives in the form of income tax-free for 5 years for companies investing in the cluster causes backward and forward linkages of vertical industries, as well as horizontal differentiation. Horizontal differentiation promoting healthy competition and encourages innovation. Scale economies of the electronics industry in Taiwan got a positive distribution in the US market. Availability of reliable labor is also a factor of success Industrial Clusters in Taiwan.

\section{METHODS OF RESEARCH}

Goals to be achieved in the research development innovation capability of SMEs in East Kalimantan include: Maturation of the concept, Doing desk study and collection of data, Perform initial analysis based on the study of literature and secondary data are available, Preparing field study or field survey (direct survey and, holding a series of meetings among others with relevant government agencies, business associations and various other relevant stakeholders in the strip) with the identification of stakeholders and the development of the survey instrument, Carry out a review into the location of the area in a predetermined area and questionnaires, doing further analysis of the results obtained from activities mentioned above by using several methods, both quantitative and qualitative analysis to prioritize potential development, Making the identification and mapping of SME cluster development in the areas concerned, discuss the results of the identification of the various key stakeholders and stakeholder support; and Doing revisions or improvements to the results of the study.

\section{Methods and Analysis Techniques}

a) Descriptive Statistics Descriptive analysis is used to describe a variety of conditions and developments from time to time and updated from a variety of indicators that will be required.

b) Analysis Klassen Typology. Klassen Typology used to determine the image of the pattern and structure of economic growth in each region. Klassen typology divides essentially based on two main indicators, namely regional economic growth and per capita income areas. Through this analysis, there are four characteristics of the economic growth pattern and different structures, namely: the area of fast-forward and fast - growing (high growth and high income), advanced areas but depressed (high income but low growth), rapidly developing areas (high growth but income), and the relatively underdeveloped regions (low growth and low income) (Arsyad, 2010).

c) Overlay Analysis Analysis. Overlay is intended to look at the description of economic activity and growth potential based on the criteria that contribute criteria analysis between MRP and analysis of combinatorial analysis LQ. This overlay technique was formed through the use of overlapping (series) a map, each representing an important environmental factor (Arsyad, 2010).

d) Diamond Cluster Model. Porter (1990) suggests that the cluster is defined as "geographic concentrations of firms, suppliers, related industries, and specialized institutions that occurs in a particular field in a nation, state or city". Another definition of clusters is "the geographical concentration of industries that gain performance advantages through co- 
location". Clusters shows the relationship between the companies that also provide complementary services, including consultancy services, education and training providers, financial institutions, professional associations and government institutions that can be identified are four (4) components, namely: first, the input factor (input factor) which are variables that already exist in the industrial clusters such as human resources (human resources), capital resources (capital resources), infrastructure (physical infrastructure), the infrastructure information (information infrastructure), the infrastructure of science and technology (scientific and technology infrastructure), the infrastructure administration (administrative infrastructure), and natural resources (natural resources). Second, demand conditions (demand condition) associated with sophisticated and demanding local customers. The more advanced a society and increasingly demanding customers in the country, so the industry will always strive to improve the quality of products or innovations in order to meet the high local customer wishes. Third, and related supporting industries (related and supporting industries) for efficiency and synergy in clusters, especially in terms of transaction costs, sharing technology, information, and expertise that can be used by industry or company other woods, which is to improve the competitiveness and productivity.

\section{Data Collection Methods}

Data collection was performed using the following methods: Desk study; held to review the various regulations and policies, review literature related, and secondary data collection related to the potential of SMEs, Survey and Field Observation; Conducted a questionnaire survey to inventory / identify various potential, location of the region / location, type of industry, the type of cluster, and capture the qualitative determination enter the cluster. The survey was conducted using questionnaires, the nature of the closed and open questions, to stakeholders the objectives in this study. Meanwhile, field observations conducted to determine the actual condition of the picture of local economic conditions, depth interviews were conducted to know more about the various existing problems associated with this type of potential economic clusters developed. The discussion was conducted to determine in more depth about the various issues involved in the development of SME innovation capabilities.

\section{RESULTS AND DISCUSSION}

Industrial development Industrial Sector. Industrial development in East Kalimantan province has increased from 15398 units in 2009 to 16574 units in 2013, an increase of 1.176 units, with a growth rate of $1.86 \%$ per year. In line with this growth on the other hand the number of workers absorbed, for the same period increased from 125386153286 persons or people into employment grew an average of $5.28 \%$ per year, as well as for the average investment growth - average 4, 91\% per annum of the nominal Rp.9,09 trillion to Rp. 10.91 trillion. Industrial growth, as above, can be explained in detail, that the business unit of Small and Medium Enterprises (SME) increased from 15268 units in 2009 to 16437 units in 2013 , or an average growth of $1.87 \%$ per year.

Workers absorbed 73326 people in 2009 rose to 89862 people in 2013, with average growth rate-average of $5.31 \%$ per year, while investment of Rp. 2.95 trillion in 2009 to Rp. 5.53 trillion in the year 2013 , with an average growth rate of $19.98 \%$ per year. While the Large Industries in 2009 amounted to 130 business units and business unit increased to 137 in 2013 , with an average growth rate of $1.32 \%$ per year, while the workforce increased from 52060 persons in 2009 to 63424 people in 2013, or an increase average growth of $5.26 \%$ next year for investment decreased from Rp. 6.14 trillion in 2009 to Rp. 5.38 trillion in 2013, an average growth $-1.67 \%$ per annum for the details, the data can be seen in Table 1 .

Potential Regional Featured. In order to develop the industry in East Kalimantan, conducted through commodity development approach, and attention to a variety of commodities are developed, as well as limitations in its development, the more commodities are classified into two (2) categories, namely leading commodity and commodity Focus (potential and prospective). 
Table 1 - Industrial development in Kalimantan Timur

\begin{tabular}{|c|c|c|c|c|c|c|c|c|c|}
\hline \multicolumn{3}{|c|}{ SMEs } & \multicolumn{3}{c|}{ Big Industry } & \multicolumn{3}{|c|}{ Total Industry } \\
\hline Year & $\begin{array}{c}\text { Business } \\
\text { unit }\end{array}$ & Worker & $\begin{array}{c}\text { Investment } \\
\text { (Million } \\
\text { Rp) }\end{array}$ & $\begin{array}{c}\text { Business } \\
\text { Unit }\end{array}$ & worker & $\begin{array}{c}\text { investment } \\
\text { (Million } \\
\text { Rp) }\end{array}$ & $\begin{array}{c}\text { Business } \\
\text { Unit }\end{array}$ & worker & $\begin{array}{c}\text { Investment } \\
\text { (Million } \\
\text { Rp) }\end{array}$ \\
\hline 2009 & 15.268 & 73.326 & 2.949 .966 & 130 & 52.060 & 6.136 .403 & 15.398 & 125.386 & 9.086 .369 \\
\hline 2010 & 15.505 & 75.484 & 2.953 .516 & 131 & 52.814 & 6.643 .663 & 15.636 & 128.298 & 9.597 .179 \\
\hline 2011 & 16.056 & 85.326 & 4.989 .049 & 133 & 61.736 & 4.699 .397 & 16.189 & 147.062 & 9.688 .447 \\
\hline 2012 & 16.218 & 87.995 & 5.529 .820 & 135 & 62.567 & 4.774 .506 & 16.353 & 150.562 & 10.303 .726 \\
\hline 2013 & 16.437 & 89.862 & 5.532 .466 & 137 & 63.424 & 5.382 .185 & 16.574 & 153.286 & 10.914 .651 \\
\hline
\end{tabular}

Source: Disperindagkop \& MSME Kalimantan Timur Province.

Commodities are dominating in 10 districts / Commodities Oil Palm City is shown in Table 2.

Table 2 - Commodities Featured Products Industry Medium Large Kalimantan Timur

\begin{tabular}{|c|c|c|}
\hline 1 & Samarinda City & Fisheries, Tourism, Pepper and Coal \\
\hline 2 & Balikpapan City & Fisheries, Tourism, and Petroleum Refining \\
\hline 3 & Bontang City & Fisheries, Fertilizers and LNG \\
\hline 4 & Tarakan City & Shrimp, Chicken, and Petroleum \\
\hline 5 & $\begin{array}{l}\text { Kabupaten Kutai } \\
\text { Kartanegara }\end{array}$ & $\begin{array}{l}\text { Palm oil, rubber, rice, pepper, Banana, Pineapple, Fishing,Tourism, Coal, Gas } \\
\text { and HTI. }\end{array}$ \\
\hline 6 & Kabupaten Kutai Timur & Palm Oil, bananas, corn, rubber, coal and timber plantations. \\
\hline 7 & Kabuapten Kutai Barat & Palm Oil, Rubber, Durian, Rambutan, freshwater fishing,Coal and Gold. \\
\hline 8 & Kabupaten Pasir & $\begin{array}{l}\text { Palm Oil, rubber, rice, bananas, Fisheries, Coal and HTI. } \\
\text { Seaweed. }\end{array}$ \\
\hline 9 & $\begin{array}{l}\text { Kabupaten Penajam } \\
\text { Paser Utara }\end{array}$ & Fisheries, Pepper, Palm Oil, Durian, Rubber and HTI \\
\hline 10 & Kabupaten Berau & Oil Palm, Rubber, Rice, Soybean, Fisheries, Oil, Tourism, and Coal. \\
\hline 11 & Kabupaten Bulungan & Palm Oil, Durian, Cocoa, Fishing, Cempedak, Methanol, andHTI. \\
\hline 12 & Kabupaten Malinau & Cocoa, oil palm, pineapple, Cempedak, HTI, and Coal \\
\hline 13 & Kabupaten Nunukan & $\begin{array}{c}\text { Cocoa, Palm Oil, Fisheries, Rice Adan (Bario), Corn, Chicken Nunukan, } \\
\text { Petroleum, Industrial Plantation Forest ( } \mathrm{HTI}) \text { and Salt Mount }\end{array}$ \\
\hline 14 & $\begin{array}{l}\text { Kabupaten Tanah } \\
\text { Tidung }\end{array}$ & Palm Oil, Durian, Cocoa, Fishing, Cempedak, Methanol, and HTI. \\
\hline
\end{tabular}

Table 3 - Commodities Featured Products Industry Medium Large Kalimantan Timur

\begin{tabular}{|c|c|c|}
\hline 1. & Kayu Lapis (plywood), Mdf & Samarinda,Balikpapan,PPU,Tarakan,Kukar \\
\hline 2. & Udang Beku & Balikpapan,Tarakan,Nunukan,Kukar \\
\hline 3. & $\begin{array}{l}\text { Ind. Pengolahan } \\
\text { Kayu/sawmill }\end{array}$ & $\begin{array}{c}\text { Samarinda,Balikpapan,Tarakan,Nunukan, } \\
\text { Kukar,Berau,Bulungan,Pasir,Kutim }\end{array}$ \\
\hline 4. & Crude Palm Oil & Samarinda,Kutai,Pasir,Kutim \\
\hline 5. & Galangan Kapal & Kukar,Pasir,Samarinda,Balikpapan \\
\hline 6. & Pupuk urea \& Amoniak & Bontang \\
\hline 7. & Moulding & Samarinda,Balikpapan,Tarakan, Nunukan,Kukar \\
\hline 8. & Gas Methanol & Bulungan \\
\hline 9. & Methanol & Bontang \\
\hline 10. & Hexamethylene Tetramine & Bontang \\
\hline 11. & Melamine & Bontang \\
\hline 12. & Ind. Lem & Samarinda, Bontang \\
\hline 13. & Ind. Minyak Kelapa & Nunukan \\
\hline 14. & Pulp & Berau \\
\hline 15. & Bengkel Service & Samarinda, Balikpapan, Kubar, Kukar \\
\hline 16. & Ind. Pengolahan Rotan & Pasir, Balikpapan \\
\hline 17. & Kulit Buaya & Samarinda \\
\hline 18. & Kain Tenun Ulap Doyo & Kutai Kartanegara \\
\hline 19. & Garmen & Balikpapan \\
\hline
\end{tabular}

Commodities focus is a commodity that is used as a development candidate based on an assessment conducted in sub-criteria to consider aspects of the advantages, the interest rate comparison, merging the advantages and value of pair wise comparisons. In this focus commodities determined 5 main commodities that can be developed prospectively and any 
potential, i.e. wood, coal, oil palm, cocoa and rubber. Potential medium large industrial commodity products in Kalimantan Timur can be seen in Table 3.

Industry Centers. Center of Small and Medium Industries in East Kalimantan were recorded until the year 2013 as many as 206 centers consisting of 2,653 business units, employment reaching 8,352 people, with an investment of Rp. 73.686 billion. State of the medium and small industries is still dominated by the food industry as much as 91 industrial centers, as in Table 4.

Table 4 - State Central Small Industries of Kalimantan Timur (According to the Industrial Branch)

\begin{tabular}{|c|l|c|c|c|c|c|c|}
\hline $\mathrm{n} / \mathrm{n}$ & \multicolumn{1}{|c|}{ Cabang Industri } & Sentra & UU & TK & Investasi Rp. 000 & $\begin{array}{c}\text { Produksi } \\
\text { Rp. 000 }\end{array}$ & $\begin{array}{c}\text { BB/BP } \\
\text { Rp.000 }\end{array}$ \\
\hline 1. & Pangan & 91 & 1,033 & 2,797 & $9,663,255$ & $13,728,648$ & $12,699,431$ \\
\hline 2. & Sandang dan Kulit & 8 & 117 & 201 & $1.643,925$ & $1,432,196$ & $1,196,111$ \\
\hline 3. & Kimia dan Bahan Bangunan & 23 & 301 & 1,432 & $6,068,164$ & $5,592,199$ & $2,687,562$ \\
\hline 4. & Kerajinan & 47 & 500 & 1,144 & $8,904,436$ & $7,646,781$ & $1,852,148$ \\
\hline 5. & Logam & 21 & 440 & 1,307 & $39,240,574$ & 7.432 .741 & $4,694,115$ \\
\hline 6. & Hasil Hutan & 16 & 262 & 1,471 & $8,165,787$ & $3,524,082$ & $1,839,762$ \\
\hline \multicolumn{2}{r}{ Total } & 206 & 2,653 & 8,352 & $73,686,141$ & $37,329,020$ & 24.969 .129 \\
\hline
\end{tabular}

Source: Disperindagkop \& MSME Kalimantan Timur Province.

Industrial Area (Industrial Estate). East Kalimantan Industry Concentration is generally done by establishing industrial zones. In Concentration Industrial Area is known as an industrial estate. Industrial Estate which is a region where the concentration of the industry which is equipped with infrastructure that includes land and strategic location as well as other facilities such as electricity, water, telephone, roads and landfills. Concentration of industrial area aims to provide a positive impact for the development of the industry itself. The existence of an industrial area industry which facilitate activities will eventually encourage the growth of the industry. In general, the concept of industrial concentration region forming aims to create a special infrastructure of concentration in a limited area so as to reduce costs; to be able to attract new business by providing an integrated infrastructure in one location; to keep industries from urban areas as well as trying to reduce the environmental and social impacts of industrial use; to provide local environmental control specifically for the needs of the industrial area.

Kariangau Industrial Area (KIK). The area planned for the Industrial Zone Kariangau $(\mathrm{CIC})$ located in the coastal city of Balikpapan, the characteristics of the basis for planning the area is primed to develop an urban area that is conducive to the balance of the coastal environment and as a new growth center of the base of industrial activity. Currently, in the area already in some companies, but most of the area is still a wilderness, reeds, weeds and the like so that communities do not benefit economically because they use the land as shifting cultivation.With great location and strategic and after the enactment of Law No. 32 and 34 in 2004, the local government intends to develop the area into an industrial area with the name Industrial Estate Kariangau ( $\mathrm{CIC}$ ) for the livelihoods of our people. Kariangau planned industrial area of 5,000 hectares located in the Village of West Balikpapan Kariangau subdistrict. The first phase of the development of an area is 1989.54 hectares while the rest will be developed later. In the development of this area, the local government to divide the different functions such as port with an area of 56.5 hectares, an industrial area with 399288 hectares wide and means of support (housing, education, entertainment, and sports facilities) covering an area of 339267 hectares. At this time has issued licenses to several companies, among others: PT. Kencana Indonesia dock; PT. Andalas Earth bloom; Container Port; PT.Kutai Chip Mill; PT. Green Forestra Lestari; PT. Prosperity Paradigm; PT. Kaltim Kariangau Industry; PT. Kariangau Power; PT. Primary Mighty dock; PT. Petrosea.

Kariangau industrial area located on the edge of the regional arterial roads leading to the bridge crossing the bay Balikpapan Balikpapan, access to reach it can be done in several ways, with varying travel time. The travel time is only 60 minutes Sepinggan. It takes 45 minutes dar Balikpapan city center with regional arterial roads Balikpapan-Samarinda at 
kilometer 12.9. Only 15 minutes by speedboat from the Port of Kampung Baru, Balikpapan. Investment in the Industrial Zone will be a very important advantage because the location is very strategic Balikpapan and also supported by adequate infrastructure and the commitment of the entire the ranks of the city government to make the city the best city to invest Balikpapan.

Industrial Area Maloy (Maloy Kipi). East Kalimantan, the country is rich in natural resources, attempting to shift the superiority of coal which currently dominates the export figures in that area. The development of agriculture-based industries through the International Port and Industrial Zone (Kipi) Maloy reinforced by Presidential Instruction No. $1 / 2012$ become desperate to shift the coal empire. Target of 1 million hectares of oil palm in 2013 established East Kalimantan Governor Awang Ishak Faroek already realized and planned to be increased to 2.4 million hectares. Land area is certainly going to make the province of East Kalimantan as a producer of crude palm oil (CPO) in Indonesia. Therefore, the existence of Kipi Maloy seems to be a way to replace the natural resources which are updated as a source of regional economic growth. Kipi Maloy has two development concepts build oleo chemical industry cluster and processing of international scale plantations. This is in order to increase value added, employment and business opportunities as well as providing industrial areas with high competitiveness with the support of incentives and various facilities. The plan, the total investment needed in the industrial area reached $\mathrm{Rp}$ 4.77 trillion, with total area of 5305 hectares.

However, for the development of the first phase of 1,000 acres of land in advance with the status of truly prepared covers 577 hectares. The land area of 577 hectares of land which is located is in the appropriate conditions. The rest, a mangrove area of land that will not be disturbed because of the development will not interfere with existing ecosystems around the area which is close to the bay. Later, the region will be built olein industry, aluminum smelting industry, stearin and PFAD (palm fatty acid distillate), fatty acid industry, the biodiesel industry and cooking oil. Besides supporting the region such as ports, power plant $2 \times 100$ $\mathrm{MW}$, railways and coal terminals. In the industrial area okeokimia built CPO port with the ability diatas 100.000 DWT. On the land side was built on an area of 115.38 hectares with office facilities, workshops, fire house and a storage tank 19 units with a capacity of 3,000 tons each per unit. Noted there are 19 potential investors have already interested in investing in these locations. However, the Management Board has not been able to offer the Kipi Maloy and directing potential locations to investors.

\section{CONCLUSION}

Small and medium enterprises (SMEs) occupy an important place in the strategic and economic growth and equitable development in all countries, both developed and developing countries. SME as an economic powerhouse has been taking place by having a percentage of $90 \%$ of the total companies in most countries around the world. SMEs are the driving force behind a large number of innovations and contribute to national economic growth through job creation, investment and exports. Potential of SMEs is often not realized because of the common problems associated with size, isolation, market opportunities, standards / quality, supply chain, logistics and technology innovation. To obtain small profit margins, small entrepreneurs in developing countries do not choose to innovate products and processes as their growth strategy and improvement in the long run. The strategies used to increase SMEs in this study are develop Industrial commodity based on local resources in the context of building a sustainable industrial competitiveness and environmentally friendly through the industry cluster approach; increasing the competitiveness of local industry through a major commodity, industrial core competency areas and populist economic empowerment; develop industry that relies on potential areas of sustainable and environmentally friendly, especially agro-industrial by prioritizing the development of small industries; develop Commodities with industrial cluster development approach based commodity and prospective; strengthen linkages at all levels of the value chain in the cluster industries concerned; increase the value-added products / results and resources used industrial industry; improving supervision 
of industrial products in order to control the $\mathrm{SNI}$; the increase in small and medium industries based social economy; improved facilities and infrastructure industry; cultivate a business environment that is comfortable and conducive.

Concentration of industrial area aims to provide a positive impact for the development of the industry itself. The existence of an industrial area which facilitates activities will eventually encourage the growth of the industry. In general, the concept of industrial concentration region forming aims to create a special infrastructure of concentration in a limited area so as to reduce costs; to be able to attract new business by providing an integrated infrastructure in one location; to keep industries from urban areas as well as trying to reduce the environmental and social impacts of industrial use; to provide local environmental control specifically for the needs of the industrial area.

\section{REFERENCES}

1. Abend, C.J, (2005), In Search of Innovation Synthesis, Ideas for a Unified Innovation Theory, Technology Transfer Society.

2. Arsyad, L. (2010). Ekonomi Pembangunan, Edisi Kelima. UPP STIE YKPN, Yogyakarta

3. Bobb, K.I, (2005). Duality of Innovation: Liberation and Economic Compentitiveness, Georgia Institute of Technology.

4. Damanpour, F. (1991), Organizational innovation: a meta-analysis of effects of determinants and moderators.Acad. Mgmt. J.34: 555.90.

5. Jimenez-Jimenez, D. (2008), Fostering innovation: the role of market orientation and organizational learning; European Journal of Innovation Management, 3(11): 389-412.

6. Jones G.B, (2004), Organizational Theory, Design, and Change, Prentice Hall.

7. Li-An Ho, (2011), Meditation, learning, organizational innovation and performance; Industrial Management \&DataSystems, Vol.111, 1: 113-131.

8. Light, P. (1998), Sustaining Innovation: Creating nonprofit and Government Organizations That Innovation Naturally, Jossey-Bass Publishing.

9. Maldique, M., \& Patch, P, (1988), Corporate Strategy and Technological Policy in Reading in the Management of Innovation, Ballinger Publishing Company, Cambridge.

10. Mansfield, E. (1988) The Speed \& Cost of Industrial Innovation in Japan and United States; Journal Management Science, 10:1157-1188.

11. Pavitt, K, (2005), Innovation processes, in Fagerberg, J., Mowery, D.C. and Nelson, R.R. (Eds), The Oxford Handbook of Innovation, Oxford University Press, Oxford, 86-114.

12. Porter, M.E, (1990), The Competitive Advantage of Nations, The Free Press, New York

13. Robey, Daniel, Maria C. B, Gregory M. Rose, (2000), Information Technology and Organizational Learning: A Review and Assesement of Research; Accounting, Management and Information Technology, 10: 125-156.

14. Subramanian, A. (1996), Organizational innovativeness: exploring the relationship between organizational determinant of innovation, types of innovations and measures of organizational performance.International Journal of Management Science, 24(6): 631-47.

15. Terziovski, Mile, \& Marianne, Gloet. (2004), Exploring the relationship between knowledge management practices and innovation performance; Journal of Manufacturing Technology Management, Volume 15, Number 5, 402-409.

16. Thomson, J.H., \& Ewer, S.R, (1989), How Should R\&D Report and Expwnditures; Research and Development, 31, 174-176.

17. Tushman, M.(1986) Organizing for innovation; California Management Review, 28:74-92.

18. Vigoda Gadot, A. Shoham, Nitza Schwabsky \& A Ruvio, (2005), Public Sector Innovation For Europe; A Multinational Eight Country Exploration of Citizens Perspectives; Journal Compilations, Public Administration, Vol 86, 2: 307-329.

19. Zahra. S.A. (1994), Innovation Strategy and Financial Performance in Manufacturing Companies: An Empirical Study; Production and Operation Management, 2, 1: 15-23. 